\title{
Assessing and Comparing Top Accelerators in Brazil, India, and the USA: Through the Lens of New Ventures' Performance
}

\author{
Snehal Shetty, Ranjany Sundaram, Krishnashree Achuthan
}

\begin{abstract}
A B S T R A C T
Objective: The objective of this article is to assess and compare the factors influencing the performance of new ventures within top business accelerators across three countries using the Resource Based View (RBV) theory.

Research Design \& Methods: The key analysed parameters are funding dimensions, survivability, acquisition, and growth of 1286 new ventures that graduated from the top two accelerators in Brazil, India, and the USA, i.e. countries from developed and emerging economies. Methods we used were machine learning and two independent sample t-tests.
\end{abstract}

Findings: Input seed funding by accelerators played a dominant role and improved funding trajectories. The external ecosystem was an important differentiator and impacted new ventures' survivability, growth, and funding outcomes. Capabilities and competencies of accelerators differentiated outcomes within the same ecosystem while external environment dampened accelerator outcomes in emerging economies.

Implications \& Recommendations: Accelerators from emerging ecosystems should strive to augment their human capital and network capabilities, including seed funding, while policy-makers should improve ecosystem index values mentioned in this study.

Contribution \& Value Added: This is the first of its kind study that extended the RBV theory to accelerators and disentangled the effect of the external environment and RBV on accelerators across three ecosystems with a comprehensive framework of measures. It provides value to practitioners in India and Brazil by highlighting lacunae in their accelerator programs and possible approaches to address them successfully.

\begin{tabular}{|c|c|}
\hline Article type: & research article \\
\hline Keywords: & accelerators; Resource Based View; start-ups; funding; performance \\
\hline JEL codes: & $\mathrm{M} 13, \mathrm{~L} 26,057$ \\
\hline
\end{tabular}

\section{Suggested citation:}

Shetty, S., Sundaram, R., \& Achuthan, K. (2020). Assessing and comparing top accelerators in Brazil, India and USA: Through the lens of new ventures' performance. Entrepreneurial Business and Economics Review, 8(2), 153-177. https://doi.org/10.15678/EBER.2020.080209 


\section{INTRODUCTION}

New ventures stimulate economic growth by driving innovations, improving productivity, and creating jobs (Acs \& Armington, 2004). During the early stages of their development, new ventures need a constant flow of funds to meet the capital and operational requirements to sustain and scale operations. But these firms face the liability of newness and the colossal task of gaining legitimacy with various stakeholders, especially investors who hesitate to invest (Hsu, 2007). Over the past decade, new ventures have increasingly joined accelerators to obtain legitimacy and initial funding. Accelerators have become a stimulating phenomenon yielding unique and astounding successes. Furthermore, accelerators have overcome many of the inadequacies of prior business incubators and are viewed as the new generation incubation model (Pauwels et al., 2016).

Accelerators provide input seed funding, mentorship, network connections, and increased exposure to investors. Moreover, accelerators have clearly outpaced business incubators as the preferred choice for input seed funding and exposure to future investors (Cohen \& Hochberg, 2014). Using a multiple case study approach, Radojevich et al. (2012) found that resources provided to accelerated start-ups help them become sustainable businesses with close to $70 \%$ increase in future funding, getting acquired, and having decreased failure rates.

Although accelerators have rapidly emerged as critical players in the start-up ecosystem, there is a paucity of literature on accelerators and limited study on their efficacy (Cohen \& Hochberg, 2014). The extant literature on accelerators focuses mostly on theoretical aspects, exploratory case studies, and selection criteria (Uhm et al., 2018). Multiple past studies cite only a partial understanding of accelerators, and these studies primarily focus on the USA and accelerators based in developed economies (Smith \& Hannigan, 2015; Hallen et al., 2014). The literature lacks a theoretically grounded study of accelerators in emerging economies and their comparison to accelerators in developed economies. Since emerging economies are transitional in nature and have higher degrees of uncertainties (Lyles et al., 2004), the application of similar resources by accelerators would have different impacts. Considering the impact that accelerators have on new ventures in terms of survival and growth (Radojevich et al., 2012), we should study their characteristics and compare and contrast their offerings and performances across both developed and emerging economies.

Thus, the research questions we posit are the following:

1. Do new ventures benefit from accelerator programs when more resources are invested in them, and is it irrespective of the economic status of the country from which they operate?

2. What role does external environment play in the growth and survival of accelerated new ventures?

The study makes several contributions. Firstly, by examining the leverage provided by resources and competencies of accelerators, we explore the extent by which accelerators impact the performance of new ventures. The lack of a comprehensive set of performance measures has hitherto led to contradictory results, as the focus on specific measures delivered varied results due to constricted view (Hallen et al., 2014). Accelerators are heterogeneous in nature with different design elements and diverse goals, so the same set of 
measures cannot be used to analyse all accelerators (Pauwels et al., 2016). A governmentbacked accelerator has different objectives compared to a deal-flow accelerator that receives funding from private investors. The evaluation of a homogenous set of accelerators and building an inclusive set of success measures to assess them is recommended. Pauwels et al. (2016) state the need to understand the impact of accelerators through the analysis of portfolio ventures performance as there is limited literature in this area. Using a comprehensive set of measures, we analysed the efficacy of a homogenous set of six deal-flow accelerators, assessed the resources provided by them, and quantified the performance of their 1286 graduated new ventures across four major dimensions, viz. funding, survivability, acquisition, and growth. Since deal-flow accelerators receive funding from private investors like business angels or venture capital funds (VC), their core objective is to identify and fund investable ventures (Yang et al., 2018), so we introduced four variables to focus on the ventures' funding performance. These approaches overcome the abovementioned three limitations, viz. 1) homogenous assessment, 2) need for an inclusive set of measures, and 3) the lack of portfolio ventures' analysis.

Secondly, from a practitioner and policy perspective, we explored the importance of three-dimensional human capital, network capabilities, and external ecosystems for accelerators. Most past studies consider network capabilities in terms of seed funding and investor/mentor network, and that too from a qualitative perspective, but they do not view it from the other two dimensions, viz. human capital and external ecosystem (Radojevich et al., 2012; Cohen et al., 2019). Using the abovementioned resources and performance parameters, our study proposes a framework applicable in the multi-dimensional assessment of accelerators. This article is the first to present a study on accelerators across three different ecosystems: one mature/developed (in the USA) and the other two in the emerging stages (Brazil and India).

Thirdly, from a research perspective, this study is among the first few that apply RBV theory to accelerators. Although there is significant literature on the application of RBV to incubators, there is very few on accelerators (Eveleens et al., 2017). This is possibly the first study to extend RBV by analysing the external environment effect on accelerators and propose that it plays an intrinsic role in the resources offered by them and creates a dampening effect on the performance of accelerators.

From a methodological perspective, we first scrutinise the resource distribution across accelerators, followed by comparisons for various output performance measures using machine learning techniques and two independent sample t-tests. Robustness tests were also completed using resampling method and machine learning.

The rest of the paper is organised as follows. The next section explores the literature review, followed by incorporated methodology, results, discussion, implications, and limitations of study.

\section{LITERATURE REVIEW}

\section{The Need for Accelerators}

The emergence of accelerators has transmuted traditional mechanisms of enterprise support that occur through incubation, business support institutions, and venture capitalist investment (Cohen \& Hochberg, 2014; Dahms \& Kingkaew, 2016; Lisowska, 2016). Accel- 
erators are either organisations or programs offered within them with structured and intensive mentorship to a set of selected start-ups as cohorts (Goswami et al., 2018). Through immersive engagement and their networks, accelerators can overhaul several aspects of start-up's strategy such as legitimacy, financial sustainability, scaling plans, human capital, the applicability of innovation in unexplored domains in syncopated timeframes spanning between three to six months (Hochberg, 2016).

Intensive mentorship and social networking are pivotal to the successes of accelerated companies, which improves sustainability (Radojevich et.al., 2012) due to the resources they receive in comparison to non-accelerated start-ups (Hallen et al., 2014). Accelerators offer services that propel the growth of new venture firms, which increases the latter's profitability by $12 \%$ at advanced stages of development. (Cacciolatti et al. 2020). However, the question remains unanswered what are the broad set of performance measures of new venture firms that directly map the objectives of deal-flow accelerators.

\section{The Assessment of Accelerators and New Venture Firm Performance}

The literature on accelerators can be classified into two major streams with some focusing on exploratory case studies, theoretical aspects, and role in the entrepreneurial ecosystem (Kim \& Wagman, 2014; Battistella, 2016, Kanbach et al., 2016), while others on the impact of accelerator programs on its portfolio ventures (Hallen et al., 2014; Smith \& Hannigan, 2015). The stream that analyses impact is undermined by the lack of data, due to the fact that accelerators are a recent phenomenon, which requires a gestation period to study the effects leading to two major gaps.

Firstly, due to the reliance of single measures and the use of subjective methods, most studies are limited in how they capture the performance of new ventures (Eveleens et al., 2017; Murphy et al., 1996, Xu et al. 2020). Subjective methods do not directly measure performance but utilise theoretical assumptions of improved resources, learning, and social capital. Hence, a comprehensive set of measures is necessary (Bøllingtoft, 2012).

Secondly, past studies on performance measurements compare different types of accelerators on the same platform, which creates misleading results in terms of contributing factors and outcomes of accelerators (Hallen et al., 2014; Gonzalez-Uribe \& Leatherbee, 2018), as the homogenous assessment of accelerators is important. Three types of accelerators based on the differences in the obligations of respective sponsoring organisations (Pauwels et al., 2016), viz. deal-flow, corporate, and welfare accelerators cannot be compared with the same set of measures.

In their diffusion studies, Xu et al. (2020) effectively show the large impact investors have on new venture firms, when the latter explicitly defines their focus areas. Accelerators improvised the time velocity of funding (Hallen et al., (2014) and increased the speed of exit (Smith \& Hannigan, 2015). Though the above studies conclusively proved that accelerators improve the speed of funding, we should consider if this impacts total funding. We require multiple factors to comprehensively measure the funding performance of new ventures (Hsu, 2007; Zur, 2013). As new ventures grow and scale their businesses, they continuously scout for sources of funding, which leads to multiple rounds of funding, the number of investors attracted, and later investment stages that, in turn, become important parameters to measure funding performance (Mayer-Haug et al., 2013; Shetty \& Sundaram, 2019). The higher the investor's prominence, the more the future funding 
raised by the new ventures (Ko \& McKelvie, 2018), as the entity's prominence signals future investors to also invest. The prominence of top accelerators included in our study should act as signals to investors and enable the ventures to raise more funding by attracting a large number of investors through multiple rounds of funding.

In summary, the impact of accelerators could be better understood by choosing a homogenous set and analysing the performance of portfolio ventures across various factors listed above.

\section{The Resource Based View Theory and Its Application to Accelerators}

The RBV theory advocates the concept of a firm as a bundle of resources and capabilities that drive firms' competitive advantages, revenues, and profits (Penrose \& Penrose, 2009). Resources can vary from financial, physical, human, and technological to reputational and organisational values (Grant, 1991). However, at a higher level of aggregation, in addition to resources, firm competencies play a more distinct role in how the resources are managed and these drive different results (Grant, 1991). This explains why two firms with similar resources and within the same ecosystems may perform differently based on their individual competencies (Toni \& Tonchia, 2003).

This study explores RBV to understand both tangible and intangible resources of accelerators and whether the accelerators capitalise on these resources effectively to drive performance. Considering accelerators essentially are firms, it becomes clear they need to extend resources that have valuable characteristics to the new ventures they nurture so as to create an impact (Amit \& Schoemaker, 1993).

Besides internal resources, the external environment and its interaction with accelerators is also an influential factor that we should considered (Hart, 1995). Accelerators have proliferated across multiple ecosystems with distinct traits and characteristics that are specific to their regional environments. The ecosystem, the linkages that the accelerators have built with partners and mentors, and the investment climate in that specific ecosystem could impact their performance.

We analyse the application of RBV on accelerators by examining the factors related to human capital, network capabilities, and the ecosystem.

Human Capital. The human capital theory examines the capabilities of people involved in a firm (Bryl \& Truskolaski, 2017). Our study extended the human capital theory to accelerators to view it as a resource by integrating its interplay with the RBV theory by specifically measuring the human capital of accelerators' founders and validating how the resources translate into better management and competence of accelerators. Since accelerators are structured as fixed-length and time-compressed programmes, human capital at accelerators will largely determine how the internal processes are designed to be efficient and goal-oriented with respect to the performance of the ventures (Wise \& Valliere, 2014). Teams with a strong industry and management expertise enable accelerators to build strong associations within the industry for market access, influence potential partnerships, and build social networks with important stakeholders. Prior start-up experience is another important aspect of human capital that relies on the premise of experiential learning and is a crucial resource for new ventures (Hsu, 2007).

Network Capabilities. The most prominent added value provided as part of the network capabilities are seed funding, mentorship, and access to a large investor network 
(Hochberg, 2016). Since accelerators make the first round of investment in these new ventures, they are driven to increase the value of their investment or obtain an exit for investment with superior returns in the near future (Yang et al., 2018).

Ecosystem. The external environment that firms interact with to substantiate their offerings plays a major role in the RBV theory (Toni \& Tonchia, 2003). If the external environment is weak, then the resources and capabilities of firms are affected (Porter, 1991). Accelerators moderate the relationship of new ventures with the external environment by acting as a bridge to external contextual contingencies (Amezcua et al., 2013, Bloom et al., 2012). To understand how external ecosystems influence the performance of accelerators (Cohen et al., 2019), we must compare and contrast mature ecosystem: the USA with emerging ecosystems, in our case India and Brazil.

Deal-flow accelerators are funded by private investors (business angels and VC funds) with specific goals to find attractive investment opportunities, mentor them and eventually exit these investments for profitable returns (Smith et al., 2015). In a study of Indian new ventures, Shetty and Sundaram (2019) found that the amount of funding raised in subsequent rounds improved significantly when the funding raised in the first round was higher. It is important for accelerators to increase the amount of input seed funding to raise funding outcomes (Gonzalez-Uribe \& Leatherbee,2018).

We selected top accelerators in Brazil and India to represent weak ecosystems. These emerging ecosystems are transitional in nature and have higher degrees of uncertainties (Lyles et al., 2004). From the costs of starting a business to difficult regulatory frameworks and limited salvage recovery from investments in failed ventures, these ecosystems significantly increase the risk of these investments (Stel et al., 2007). In a study of VC investment across five countries, Manigart et al. (2002) found investors resisted to invest in less promising ecosystems. Investors would invest in ventures from top accelerators that are capable of scouting new ventures, providing a higher amount of resources such as input seed funding and mentoring only if the local ecosystem is also favourable. Therefore, we propose the first hypothesis:

H1: New ventures accelerated in accelerators that provide higher resources and operate from a better ecosystem will raise large funding.

Ecosystems have a direct bearing on the growth and, eventually, survival of ventures. New ventures rely on the health of the local ecosystem for venture development, and they are adversely affected by environmental uncertainties. The proposition that environmental uncertainty is a determining factor for the survival of an organisation is well-researched (Scherer, 1980). Developing ecosystems grapple with environmental uncertainties from both economic and political perspective. Changes in the regulatory framework, restrictions on exports, complicated tax structures, and the instability of political institutions are multiple issues faced in emerging countries (Meschi \& Riccio, 2008). Founders at high-technology ventures directly compete with other ventures in developed ecosystems and the intricacies of the local ecosystem could distract and affect their performance. Although good accelerators provide excellent support systems through various resources such as mentoring and network connections, they could alleviate only some of the hurdles faced by new ventures. Nevertheless, for superior growth and survival, ventures not only need a top accelerator but eventually also a favourable local ecosystem. Therefore, we propose the following hypotheses: 
H2: New ventures accelerated in accelerators that provide higher resources and operate from better ecosystems will see stronger growth.

H3: New ventures accelerated in accelerators that provide higher resources and operate from better ecosystems will survive longer.

Summarising the literature and its gaps, many studies on accelerators focus on either theoretical aspects or exploratory case studies, possibly due to the limited availability of data (Radojevich et al., 2012; Goswami et al., 2018). Secondly, studies on critical accelerator parameters (Hochberg, 2016, Hallen et al., 2014) are not directly linked to new ventures' performance. Thirdly, the impact of the external ecosystem on the resources offered by accelerators is neglected (Cohen et al., 2019). Finally, there also remains a significant bias in the literature towards the study of accelerators in mature and advanced entrepreneurial ecosystems. Almost $90 \%$ of the literature observes accelerators and startups primarily based in the USA and Europe (Smith \& Hannigan, 2015; Wise \& Valliere, 2014). The contribution of our study addresses these gaps by: 1) discerning the role of accelerators homogenous in nature to ensure comparisons are precise and accurate with respect to four major performance-output parameters, i.e. the funding, survivability, growth, and acquisition performance of new ventures over a two-year gestation period; 2) utilising the RBV framework to analyse the theoretical underpinnings of accelerators and their resources' functional roles; and 3) performing a quantitative analysis of over 1200 ventures across six accelerator programs in three countries with a widely varying ecosystems so as to draw insights on distinctive features and critical parameters towards accelerator strategies, their performance, and their impact on new venture firms.

\section{MATERIAL AND METHODS}

The objective of the methodology is to theoretically ground the study on RBV theory and compare and contrast multiple ventures that are part of the accelerator programs across developed and emerging economies.

\section{Empirical Context and Data}

Empirical analysis was completed on a sample of 1286 new ventures that went through six accelerator programmes across three countries during the four-year period from January 1, 2013, to December 31, 2016. To analyse the new ventures post-acceleration, we observed their performance over a two-year gestation period (Hallen et al., 2014) until December 31, 2018. The study included 1145 new ventures from the USA, 77 from Brazil, and 63 from India.

Based on a defined set of criteria (Hallen et al., 2014), the top two accelerators from each country were selected for this study. Accelerators were shortlisted based on the following criteria: 1 ) the design theme and architecture of a deal-flow accelerator; 2 ) at least four graduate ventures that closed more than one round of funding; 3 ) provision for seed capital upon acceptance; 4 ) well established presence in their respective countries; 5) in existence at least a year before the study period; 6 ) hold a demonstration day with external investors. 
The firms selected for the study were Y-Combinator (YCOM) and Techstars from the USA, Ace Startups (ACE) and Wow Accelerator (WOW) from Brazil, and Global Super Angels Forum (GSF) Accelerator and TLABS from India. In this work, we compare and contrast the performance of only top two accelerators in each country. Comparing the top accelerators served the purpose of understanding the gap in accelerator resources and performance among accelerators that have demonstrated consistent impact on start-ups in their respective environments. Considering mediocre accelerators would have made the study challenging due to a multitude of factors that impact their poor longevity and inconsistent performance in Brazil and India. This work directly impacts practitioners in India and Brazil and helps to provide an understanding of gaps in their accelerator programmes that they must address to create successful ventures.

The Crunchbase database was used for this study, as it is a comprehensive database of investments, funding, acquisitions, and investors for new ventures (Eugene \& Yuan, 2012). Crunchbase is viewed as one of the most prominent and comprehensive databases of new ventures (Block \& Sander, 2009). We also validated our data through individual accelerator websites, new venture firm websites, media articles, and Linkedln. Global Entrepreneurship Monitor (GEM) and World Bank's Doing Business database for the four years of study was obtained to analyse ecosystem offerings in each of the three countries.

The Global Entrepreneurship Monitor database is developed by one of the largest and most developed research programs on entrepreneurship in the world (Bosma, 2013). Doing Business is a World Bank Group flagship publication currently in the 17th series, an annual study that presents quantitative indicators measuring the regulations that enhance business activity and constraints across 100+ economies (Business D, 2013). Both these databases have been widely used for research in entrepreneurship and ecosystem offerings of various countries (Wong et al., 2005; Corcoran \& Gillanders, 2015).

\section{Measures}

We conducted the following analyses for this article:

1. Two independent sample t-test to differentiate performance. Robustness test was done through a resampling method.

2. Prediction models across three Machine Learning techniques, namely Support Vector Machine (SVM), Random Forest, and Neural Networks.

We used two independent sample t-test, meaning an inferential statistical test that determines whether there is a statistically significant difference between the means in two unrelated groups. In this study, we compared top two accelerators in each country under study to understand which one between performs better. Next, we compared the accelerators' performance among the three scrutinised countries.

To learn complex mapping from input to the output space and to understand the regression relationships, we analysed the data using three machine learning techniques, viz. Support Vector Machine, Random Forest, and Neural Network methods.

Scree plot was used to understand the number of variables influencing the outcome. Scree Plot is a simple line segment plot that shows the fraction of total variance in the data as explained by each principal component. A clear separation point called 'elbow' separates the most important from the least important components. After finding out the number of important variables, we used Random Forest to attribute importance and 
analyse which variables played a significant role in the funding, growth, and survival outcomes of accelerated ventures.

We conducted the Ryan-Joiner normality test to assess if the data is normally distributed. The Ryan-Joiner test passed normality with a p-value above 0.10 . Levene's test for equality of variances showed p-value greater than 0.05 , which indicates that the group variances are equal in the population.

\section{Variables: Accelerator Resources}

Industry experience was calculated as the sum of years each founder spent in the industry in technical and managerial roles prior to the study period. Prior start-up experience refers to the total number of years the founders gained at founding new ventures before the study period.

As in previous studies, this article characterises network capabilities by input seed funding, mentor network, and investor network (Hallen et al., 2014; Eveleens et al., 2017).

Ecosystem variables are viewed from two perspectives in this study: 1) the macro perspective (Klyver, 2008), characterised by Total Entrepreneurship Activity (TEA) and Total Innovation, and 2) the business perspective (Business D, 2013) that includes 'starting a business score,' 'starting a business cost,' 'getting a credit score,' 'recovery rate (cents on the dollar).' TEA and Total Innovation values were obtained from the Global Entrepreneurship Monitor(GEM) database. All the Business perspective variables were obtained from the World Bank's Doing Business database.

Figure 1 represents the three input resource categories representing 12 variables and four output/performance categories representing eight variables.

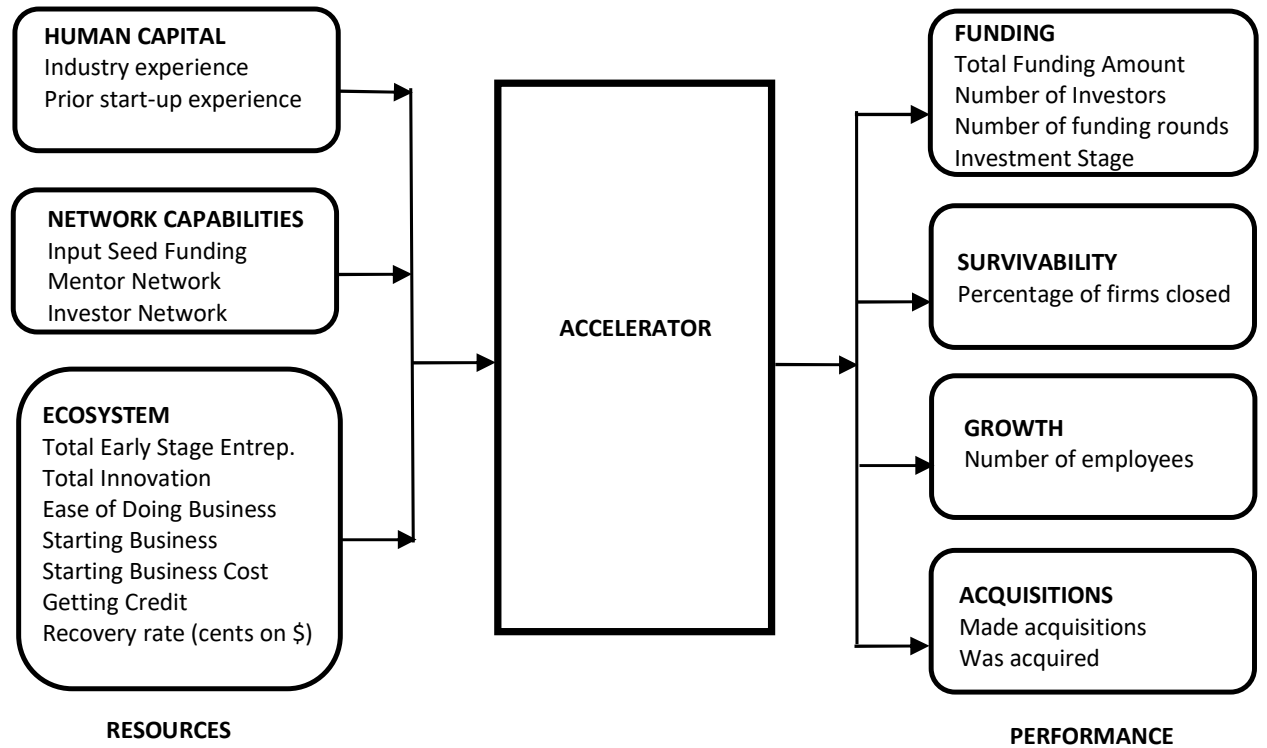

Figure 1. The performance assessment of accelerators

Source: own elaboration based on literature review and data collected. 


\section{Variables: Accelerator Performance}

The variables used for the measurement of performance are classified into four major categories, viz. Funding Dimensions, Survivability, Acquisition, and Growth variables.

Funding Dimension is a critical performance parameter for deal-flow accelerators (Pauwels et al. 2016), so it is important to comprehensively analyse multi-funding parameters to obtain a complete picture (Ko \& McKelvie, 2018; Shetty \& Sundaram, 2019). The multiple parameters are Total funding amount, Number of funding rounds, Number of Investors, and Investment Stages. Survivability is the measure of the firm's operational status. Brazil and India face challenging regulatory issues related to the closure of businesses, both in terms of resolving insolvencies and the time taken to officially shutdown a firm. For example, in both Brazil and India, it takes up to four years to close a business (Business $D, 2013)$. Our study used website traffic as an additional metric to validate the operation of business. Acquisition dimension has two variables, viz. Made Acquisitions and Was Acquired. The growth of a firm is measured by the number of employees. The measurement of the number of employees is an effective firm growth measure (Hallen et al., 2014).

\section{RESULTS AND DISCUSSION}

\section{Resources of Accelerators}

Table 1 highlights the homogenous nature of the selected accelerators and their various characteristics.

Table 1. Accelerator descriptions

\begin{tabular}{|c|c|c|c|c|c|c|}
\hline Parameters & YCOM & Techstars & ACE & wow & GSF & TLABS \\
\hline Location & \begin{tabular}{|c|} 
Silicon \\
Valley, the \\
USA \\
\end{tabular} & $\begin{array}{l}\text { Multiple cit- } \\
\text { ies, the USA }\end{array}$ & $\begin{array}{c}\text { Multiple cit- } \\
\text { ies, Brazil }\end{array}$ & $\begin{array}{l}\text { Porto Ale- } \\
\text { gre, Brazil }\end{array}$ & $\begin{array}{l}\text { New Delhi, } \\
\text { India }\end{array}$ & $\begin{array}{l}\text { Bengaluru, } \\
\text { India }\end{array}$ \\
\hline Program Type & On-site & $\begin{array}{c}\text { On-site \& } \\
\text { virtual }\end{array}$ & On-site & On-site & On-site & On-site \\
\hline Cohorts per year & 2 & Multiple & Multiple & 2 & 1 & 2 \\
\hline Length & 3 months & 3 months & 6 months & 6 months & 5.5 months & 4 months \\
\hline $\begin{array}{l}\text { Equity stake taken } \\
\text { by accelerator }\end{array}$ & $7 \%$ & $6 \% *$ & up to $15 \%$ & up to $12 \%$ & up to $15 \%$ & $8 \%$ \\
\hline Focus Area & $\begin{array}{c}\text { Technol- } \\
\text { ogy }\end{array}$ & Technology & Technology & Technology & Technology & Technology \\
\hline $\begin{array}{l}\text { Software/Plat- } \\
\text { forms }\end{array}$ & $83.20 \%$ & $78.53 \%$ & $92.31 \%$ & $84.00 \%$ & $89.47 \%$ & $90.91 \%$ \\
\hline Major categories & $\begin{array}{c}\text { Internet, } \\
\text { E-com- } \\
\text { merce, } \\
\text { Mobile }\end{array}$ & $\begin{array}{l}\text { Internet, } \\
\text { Mobile, } \\
\text { SAAS }\end{array}$ & $\begin{array}{l}\text { Internet, E- } \\
\text { commerce, } \\
\text { Information } \\
\text { Technology }\end{array}$ & $\begin{array}{c}\text { Internet, } \\
\text { SAAS, Infor- } \\
\text { mation } \\
\text { Technology }\end{array}$ & $\begin{array}{l}\text { Internet, } \\
\text { Mobile, E- } \\
\text { commerce }\end{array}$ & $\begin{array}{l}\text { Internet, } \\
\text { Mobile, In- } \\
\text { formation } \\
\text { Technology }\end{array}$ \\
\hline
\end{tabular}

* for first tranche of 18000 USD

YCOM - Y-Combinator, ACE - ACE start-ups, GSF - Global Super Angels Forum Source: own elaboration on collected data. 
Table 2 includes the resources and capabilities of the six selected accelerators. From a human capital perspective, prior start-up experience is higher in both the USA and Brazil than in India, which portrays the fact that start-up culture is very nascent in India. The industry experience of the founders of US accelerators is comparable to that of Brazil and India. The Techstars accelerator had a significantly higher level of prior start-up experience in comparison to others.

Table 2. Resources across the six accelerators under study

\begin{tabular}{|c|c|c|c|c|c|c|}
\hline \multirow[t]{2}{*}{ Parameters } & \multicolumn{2}{|c|}{ The USA } & \multicolumn{2}{|c|}{ Brazil } & \multicolumn{2}{|c|}{ India } \\
\hline & YCOM & Techstars & ACE & Wow & GSF & TLABS \\
\hline \multicolumn{7}{|c|}{ Human Capital } \\
\hline Total Industry Experience & 11 & 9 & 0 & 9 & 0 & 13 \\
\hline Prior Start-Up Experience & 32 & 57 & 24 & 14 & 14 & 0 \\
\hline \multicolumn{7}{|c|}{ Network Capabilities } \\
\hline Input Seed Funding (USD) & 120000 & $18000 * *$ & 50000 & $\begin{array}{r}16000- \\
50000 \\
\end{array}$ & $\begin{array}{r}\text { up to } \\
200000 \\
\end{array}$ & 50000 \\
\hline Mentor Network & 4000 & 4800 & 180 & 100 & 29 & 130 \\
\hline Investor Network & $450 *$ & 2700 & 150 & 98 & 20 & 20 \\
\hline \multicolumn{7}{|c|}{ Ecosystem } \\
\hline Total Early Stage Entrep. & 12.76 & 12.76 & 18.77 & 18.77 & 9.47 & 9.47 \\
\hline TEA Total Innovation & 36.01 & 36.01 & 11.37 & 11.37 & 35.88 & 35.88 \\
\hline Ease of Doing Business & 82.43 & 82.43 & 57.07 & 57.07 & 53.45 & 53.45 \\
\hline Starting Business Score & 91.16 & 91.16 & 64.11 & 64.11 & 64.23 & 64.23 \\
\hline Starting a Business Cost & 1.16 & 1.16 & 5.40 & 5.40 & 24.13 & 24.13 \\
\hline Getting Credit Score & 95 & 95 & 45 & 45 & 65 & 65 \\
\hline Recovery rate & 82.30 & 82.30 & 22.57 & 22.57 & 25.6 & 25.6 \\
\hline \multicolumn{7}{|c|}{$\begin{array}{l}\text { * Investors on Demo Day. } \\
\text { ** Plus an optional 100,000 USD in convertible note. } \\
\text { YCOM - Y-Combinator, ACE - ACE start-ups, GSF - Global Super Angels Forum } \\
\text { Source: own elaboration of collected data. Ecosystem data was collected from GEM and World Bank's Doing } \\
\text { Business database. }\end{array}$} \\
\hline
\end{tabular}

The mentor and investor network capabilities of US accelerators are nearly 20 times higher than Brazilian accelerators and 30 times higher than Indian accelerators. Overall, the human capital and network capabilities parameters are much higher in the USA. Between Brazil and India, Brazil has higher resources in all listed parameters (Table 2) except for input seed funding. The accelerators that invest higher input seed funding are YCOM from the USA, ACE from Brazil, and GSF from India. As shown in later tables, these accelerators perform better.

The USA leads all ecosystem parameters followed by India in most parameters and then Brazil. It is very easy to start a business, with a very low cost, and get a very high recovery rate if the business closes in the USA. This indicates a very positive environment for founders to start a business in the USA. The cost of starting a business in India is significantly higher.

\section{The Performance of Accelerators}

As seen across various tables, in the mature US ecosystem, the differences are magnified across multiple parameters. Specifically, new ventures at YCOM can raise more funding and have better growth in terms of employees. 
Table 3. Difference in accelerator performance measures in Brazil

\begin{tabular}{|l|r|r|r|}
\hline \multirow{2}{*}{$\begin{array}{c}\text { Accelerator Performance } \\
\text { Measures }\end{array}$} & ACE & \multicolumn{1}{c|}{ WOW } & t-value \\
\cline { 2 - 4 } & \multicolumn{3}{c|}{ Funding } \\
\hline Total Funding amount & 12.290 & 11.040 & $3.28^{* * *}$ \\
\hline Number of Investors & 0.320 & 0.453 & -0.970 \\
\hline Number of funding rounds & 0.300 & 0.180 & 1.100 \\
\hline Investment Stage & 0.731 & 0.737 & -0.160 \\
\hline \multicolumn{3}{|c|}{ Survivability } \\
\hline \% of closed firms & 13.462 & 24.000 \\
\hline \multicolumn{3}{|c|}{ Growth } \\
\hline Number of employees & 2.193 & 0.590 \\
\hline \multicolumn{3}{|c|}{ Acquisitions } \\
\hline Made acquisitions & 1.923 & - \\
\hline Was Acquired & 9.615 & - \\
\hline
\end{tabular}

$* * * \mathrm{p}<0.01,{ }^{* *} \mathrm{p}<0.05, \mathrm{p}<0.1$

ACE - ACE start-ups

Source: own elaboration of statistical analysis.

The performance difference between accelerators in Brazil and India is not as high as in the USA. In Brazil (Table 3), ACE leads WOW in the funding amount ( $t=3.28, p<0.05)$, while all other differences are not statistically significant. In India (Table 4), GSF leads TLABS in the amount of funding and the number of investors ( $t=5.14$ and $t=2.85$ with $p<0.01$ ).

Table 4. Difference in accelerator performance measures in India

\begin{tabular}{|c|c|c|c|}
\hline \multirow{2}{*}{ Accelerator Performance Measures } & \multicolumn{2}{|c|}{ Mean } & \multirow{2}{*}{ t-value } \\
\hline & GSF & TLABS & \\
\hline \multicolumn{4}{|c|}{ Funding } \\
\hline Total Funding amount & 14.170 & 11.620 & $5.14 * * *$ \\
\hline Number of Investors & 1.249 & 0.554 & $2.85 * * *$ \\
\hline Number of funding rounds & 0.737 & 0.504 & 1.360 \\
\hline Investment Stage & 0.915 & 0.830 & 1.250 \\
\hline \multicolumn{4}{|c|}{ Survivability } \\
\hline$\%$ of closed firms & 21.053 & 25.000 & - \\
\hline \multicolumn{4}{|c|}{ Growth } \\
\hline Number of employees & 2.865 & 2.840 & 0.080 \\
\hline \multicolumn{4}{|c|}{ Acquisitions } \\
\hline Made acquisitions & - & 6.818 & - \\
\hline Was Acquired & - & 4.545 & - \\
\hline
\end{tabular}

***p $<0.01,{ }^{* *} \mathrm{p}<0.05,{ }^{*} \mathrm{p}<0.1$

GSF - Global Super Angels Forum

Source: own elaboration of statistical analysis. 
Table 5. Difference in accelerator performance measures in the USA

\begin{tabular}{|c|c|c|c|}
\hline \multirow{2}{*}{ Accelerator Performance Measures } & \multicolumn{2}{|l|}{ Mean } & \multirow{2}{*}{ t-value } \\
\hline & YCOM & Techstars & \\
\hline \multicolumn{4}{|c|}{ Funding } \\
\hline Total Funding amount & 14.370 & 14.060 & $2.49 * *$ \\
\hline Number of Investors & 1.630 & 1.739 & $-2.12 * *$ \\
\hline Number of funding rounds & 0.836 & 1.002 & $-4.71 * * *$ \\
\hline Investment Stage & 0.957 & 0.940 & 0.900 \\
\hline \multicolumn{4}{|c|}{ Survivability } \\
\hline$\%$ of closed firms & 4.510 & 4.175 & - \\
\hline \multicolumn{4}{|c|}{ Growth } \\
\hline Number of employees & 2.850 & 2.530 & $4.69 * * *$ \\
\hline \multicolumn{4}{|c|}{ Acquisitions } \\
\hline Made acquisitions & 4.666 & 2.982 & - \\
\hline Was Acquired & 9.331 & 10.736 & - \\
\hline
\end{tabular}

YCOM leads Techstars in terms of total funding amount raised by start-ups $(\mathrm{t}=2.49$ and $p<0.05)$. YCOM start-ups frequently progress to later investment stages. Moreover, YCOM start-ups lead in survival and growth (Employees growth $t=4.69$ with $p<0.01$ ). Techstars leads in the number of investors involved with their start-ups $(t=-2.12, p<0.05)$ and funding rounds $(t=-0.471, p<0.01)$ that their start-ups raised, but overall performance in terms of growth and survival is poor.

Table 6 shows compares accelerators in the USA, Brazil, and India. There appears a statistically significant difference between accelerator performance of US and Brazilian accelerators and between US and Indian accelerators. Variables under funding category between the two sets - i.e. total funding amount, number of investors, number of funding rounds, and investment stage - have highly significant t-values with $p<0.01$. This indicates a strong difference across all funding dimensions. US ventures have better survivability rates and superior growth in terms of the number of employees as well. Overall, the table reveals the strong and significant performance of US accelerators.

India is better than Brazil in terms of numbers of investors attracted $(t=2.56$, $p<0.05)$, the number of funding rounds closed $(t=3.38, p<0.01)$, and investment stages $(t=3.52, p<0.01)$, but the $t$-value is not significant for the total funding amount. Both Indian and Brazilian firms have poor survivability rates compared to the USA. Moreover, new ventures in the USA have better acquisition performance.

The scree plot in Figure 2 shows that two variables are important in predicting the total funding amount raised by accelerated ventures. The clear separation point 'elbow' separates the most important components from the least important components. In this case, the most important components are two. This has been further explored by Random forest tests. The Cluster Dendogram highlights the close alignment of the two US accelerators. The US accelerators differ from the accelerators of the emerging economies. The Brazilian accelerators are more similar to the Indian GSF accelerator as compared to Indian TLABS accelerator. 
Table 6. Difference in accelerator performance measures across countries

\begin{tabular}{|l|r|r|r|r|r|r|}
\hline \multirow{2}{*}{$\begin{array}{c}\text { Accelerator Performance } \\
\text { Measures }\end{array}$} & \multicolumn{7}{|c|}{ Mean } & $\begin{array}{c}\text { t-value } \\
\text { the USA } \\
\text { and Brazil }\end{array}$ & $\begin{array}{c}\text { t-value } \\
\text { the USA } \\
\text { and India }\end{array}$ & $\begin{array}{c}\text { t-value } \\
\text { India and } \\
\text { Brazil }\end{array}$ \\
\cline { 2 - 7 } & The USA & Brazil & India & Funding \\
\hline Total Funding amount & 14.230 & 11.550 & 12.090 & $12.38^{* * *}$ & $7.21^{* * *}$ & 1.510 \\
\hline Number of Investors & 1.677 & 0.363 & 0.684 & $19.74^{* * *}$ & $8.76^{* * *}$ & $2.56^{* *}$ \\
\hline Number of funding rounds & 0.909 & 0.261 & 0.574 & $11.84^{* * *}$ & $4.24^{* * *}$ & $3.38^{* * *}$ \\
\hline Investment Stage & 0.950 & 0.733 & 0.856 & $11.39^{* * *}$ & $2.93^{* * *}$ & $3.52^{* * *}$ \\
\hline \multicolumn{7}{|c|}{ Survivability } \\
\hline \% of closed firms & 4.363 & 16.883 & 23.81 & - & - & - \\
\hline \multicolumn{7}{|c|}{ Growth } \\
\hline Number of employees & 2.710 & 2.154 & 2.850 & $5.07 * * *$ & -0.930 & $3.81^{* * *}$ \\
\hline \multicolumn{7}{|c|}{ Acquisitions } \\
\hline Made acquisitions & 3.927 & 1.299 & 4.762 & - & - & - \\
\hline Was Acquired & 9.948 & 6.494 & 3.175 & - & - & - \\
\hline
\end{tabular}

$* * * \mathrm{p}<0.01, * * \mathrm{p}<0.05, \mathrm{p}<0.1$

Source: own elaboration of statistical analysis.
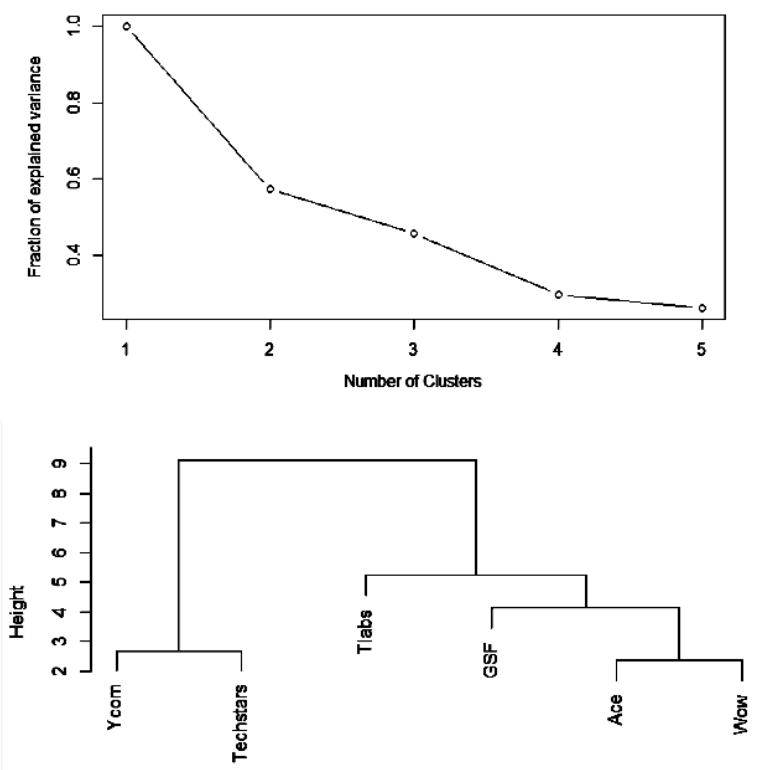

Input

hclust (", "complete")

Figure 2. Scree plot and Cluster Dendogram for hierarchical clustering of accelerator characteristics

YCOM - Y-Combinator, ACE - ACE start-ups, GSF - Global Super Angels

Source: own elaboration of statistical analysis. 
Table 7. Predicted output performance measures across various inputs

\begin{tabular}{|c|c|c|c|c|c|c|c|c|}
\hline \multicolumn{9}{|c|}{ Model-Set-1: Accelerator-only inputs } \\
\hline \multirow[b]{2}{*}{ Methods } & \multicolumn{4}{|c|}{ Funding } & \multirow{2}{*}{\begin{tabular}{|c|} 
Survivability \\
$\begin{array}{c}\% \text { of closed } \\
\text { firms }\end{array}$
\end{tabular}} & \multirow{2}{*}{$\begin{array}{c}\text { Growth } \\
\text { Number } \\
\text { of em- } \\
\text { ployees }\end{array}$} & \multicolumn{2}{|c|}{ Acquisitions } \\
\hline & $\begin{array}{c}\text { Total } \\
\text { Funding } \\
\text { amount }\end{array}$ & $\begin{array}{c}\text { Number } \\
\text { of Inves- } \\
\text { tors }\end{array}$ & $\begin{array}{c}\text { Number } \\
\text { of funding } \\
\text { rounds }\end{array}$ & $\begin{array}{c}\text { Invest- } \\
\text { ment } \\
\text { Stage }\end{array}$ & & & $\begin{array}{l}\text { Made ac- } \\
\text { quisitions }\end{array}$ & $\begin{array}{l}\text { Was Ac- } \\
\text { quired }\end{array}$ \\
\hline SVM & 1.29 & 0.55 & 0.27 & 0.08 & 0.4 & 0.25 & 0.04 & 0.06 \\
\hline \begin{tabular}{|l|} 
Random \\
Forest \\
\end{tabular} & 1.71 & 0.69 & 0.36 & 0.11 & 0.75 & 0.39 & 0.02 & 0.04 \\
\hline \begin{tabular}{|l|} 
Neural \\
Networks \\
\end{tabular} & 0.96 & 0.46 & 0.23 & 0.06 & 0.3 & 0.17 & 0.04 & 0.06 \\
\hline \multicolumn{9}{|c|}{ Model-Set-2: Accelerator-only and Ecosystem inputs } \\
\hline & \multicolumn{4}{|c|}{ Funding } & Survivability & Growth & \multicolumn{2}{|c|}{ Acquisitions } \\
\hline Methods & $\begin{array}{c}\text { Total } \\
\text { Funding } \\
\text { amount }\end{array}$ & $\begin{array}{c}\text { Number } \\
\text { of Inves- } \\
\text { tors }\end{array}$ & $\begin{array}{c}\begin{array}{c}\text { Number } \\
\text { of funding } \\
\text { rounds }\end{array} \\
\end{array}$ & $\begin{array}{c}\text { Invest- } \\
\text { ment } \\
\text { Stage }\end{array}$ & $\begin{array}{l}\% \text { of closed } \\
\text { firms }\end{array}$ & $\begin{array}{l}\text { Number } \\
\text { of em- } \\
\text { ployees }\end{array}$ & $\begin{array}{l}\text { Made ac- } \\
\text { quisitions }\end{array}$ & $\begin{array}{l}\text { Was Ac- } \\
\text { quired }\end{array}$ \\
\hline SVM & 1.77 & 0.48 & 0.2 & 0.05 & 0.32 & 0.19 & 0.07 & 0.04 \\
\hline \begin{tabular}{|l|} 
Random \\
Forest
\end{tabular} & 1.57 & 0.62 & 0.31 & 0.09 & 0.6 & 0.33 & 0.04 & 0.02 \\
\hline $\begin{array}{l}\text { Neural } \\
\text { Networks }\end{array}$ & 1.02 & 0.45 & 0.18 & 0.05 & 0.27 & 0.16 & 0.06 & 0.04 \\
\hline
\end{tabular}

Source: own elaboration of statistical analysis.

In order to accommodate for variations in machine learning (ML) techniques and to allow for a proper comparison across techniques, we have built prediction models in three ML techniques, namely Support Vector Machine (SVM), Random Forest, and Neural Networks. We modelled ML with the framework listed in Figure 1, with 12 variables used as input factors and categorised into three buckets for each of the output performance parameters across all three countries. We first applied only accelerator-inputs and then applied ecosystem inputs to observe the variation in outcomes. Model-Set- 1 in Table 7 depicts the impact of accelerator-only inputs, namely the Human capital and Network capabilities input variables. Model-Set- 2 in Table 7 depicts the impact of accelerator-only inputs and the external ecosystem variables.

We compared the predicted outcomes between the two Model-Sets to understand the influence of ecosystem. In Model-Set-2, which includes the ecosystem variables, cross-validation errors have reduced, thus indicating a better prediction for the output performance measures, which indicating the influence of ecosystem variables. The following funding parameters- number of investors, number of funding rounds and investment stage displayed better prediction outcomes when the ecosystem variable was introduced. The same effect is seen with Survivability, Growth, and Acquisitions-Was Acquired performance measures. These results validate the importance of the ecosystem on performances of accelerated ventures.

This is further validated with attribute importance by using Random Forest, which shows that the ecosystem variable plays a major role in predicting outcomes of accelerated ven- 
tures. Table 8 shows important factors that contribute to total funding raised, along with the survival and growth of accelerated ventures. As per Scree Plot, only two variables play a significant role in accelerated ventures' total funding amount. We analysed further to bring out variables that have the highest impact. These are Recovery rate and Getting credit score. Table 8 below lists variables according to importance, and we should note that all ecosystem variables are in the top of the table, which shows their dominance over local accelerator inputs. Recovery rate, Ease of doing business, and Starting a Business cost are the most important ecosystem predictors for each of performance measures.

Hypothesis 1, 2, and 3 are proved by T-stat results in Table 6 and the variable importance list in Table 8. The new ventures accelerated in the US raise more total funding, have higher growth, and survive better due to the better accelerator inputs and ecosystem variables. This is because the mentor and investor network capabilities of US accelerators are nearly 20 times higher than Brazilian and $\mathbf{3 0}$ times higher than Indian accelerators. Overall, the human capital and network capabilities parameters are much higher in the USA. Since accelerator input and ecosystem variables are of higher value, new ventures accelerated in the US perform well, which proves our three hypotheses.

Table 8. Attribute importance using Random Forest

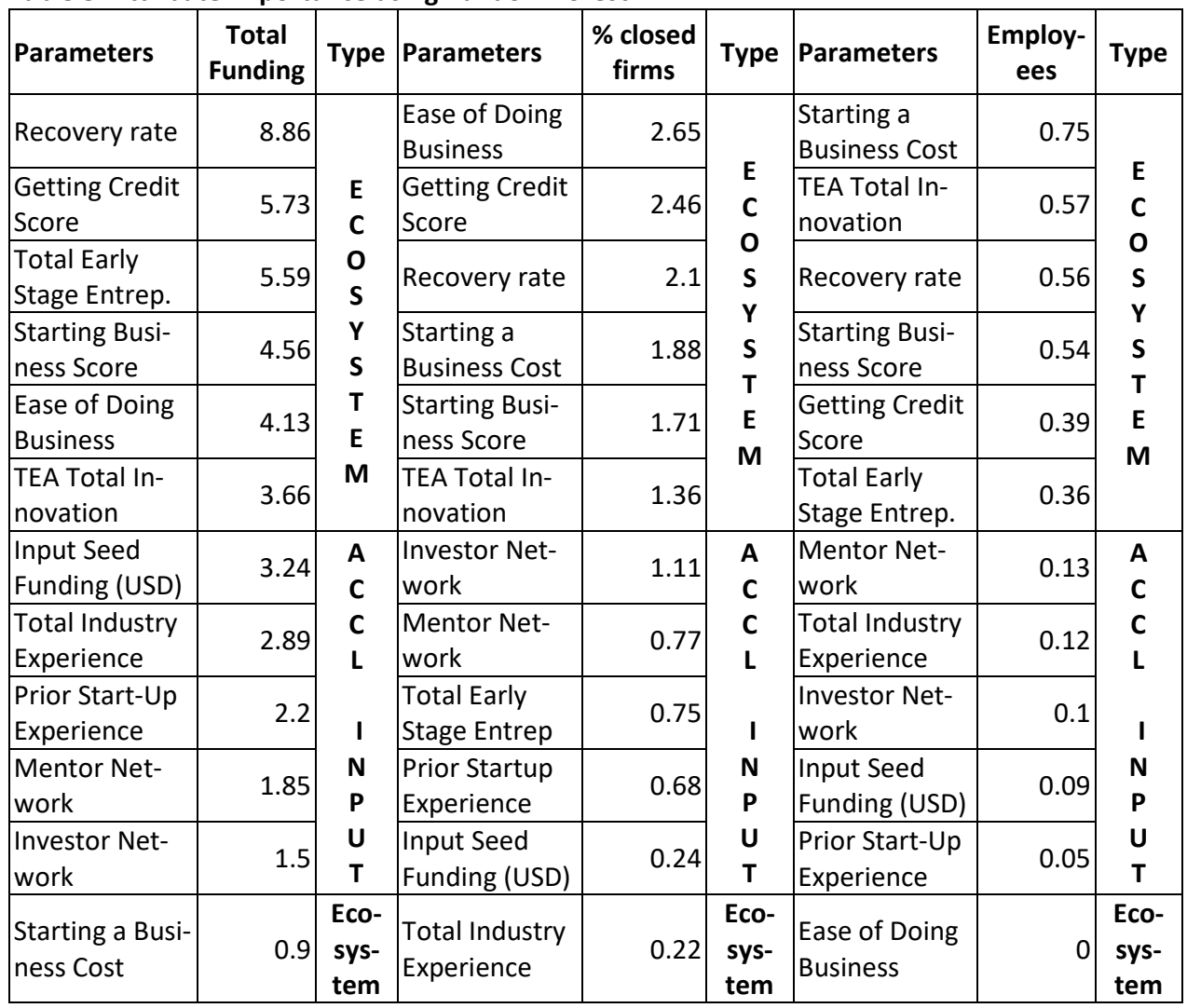

ACCL - Accelerator

Source: own elaboration of statistical analysis. 
By focusing on a specific type of accelerators called the deal-flow accelerator, we ensured that the chosen performance parameters not only match design objectives of accelerators but also are sufficiently robust and broad to provide a holistic approach to the assessment of accelerators across various ecosystems. This validates the proposition put forth by Pauwels et al. (2016) to delineate and assess accelerators based on their objectives.

Despite the fact that the accelerators selected for the study had similar characteristics and offered similar structured programmes, the outputs varied widely within the ecosystem and across ecosystems. The impact within the ecosystem and across ecosystems are examined separately and in detail below.

Variations within the ecosystem can be explained by the competencies each firm brings in to drive the results, which resonates with the reasoning provided by the RBV competency theory (Amit \& Schoemaker, 1993). More competent accelerators are adept at using the assets at their disposal and spreading resources through structured interventions with new ventures. Techstars in the USA offer a larger number of mentors and investors as resources to their ventures. Investors prefer to see commitment from other investors before they invest, so assembling a large pool of investors is crucial. Thanks to this, new ventures that graduated from Techstars were capable of attracting more investors and close more funding rounds. But the new ventures at YCOM attracted a larger amount of funding even though the resources in the form of investors were lower. As put forth by Toni and Tonchia (2003), this displays firms' strategic potential from two levels: 1) appraisal of rent-generating potential of resources, and 2) the exploitation of firm resources and competencies relative to external opportunities. Both Brazil and India need strong accelerator founders with good industry and start-up experience to successfully steer the allocated resources. These countries are highly deficient in Human capital resources. They should hire talented managers with prior experience in the technology industry, as these managers would have built connections in the industry through their professional networks, which could provide immense value to new ventures (Wise \& Valliere, 2014). The management team also must have prior start-up experience, as it delivers the much needed experience associated with running a start-up (Ko \& McKelvie, 2018). Accelerators should increase the amount of input seed funding given to new ventures, as it would serve two main purposes: 1 ) improving funding trajectories of their new ventures, and 2) providing better exits for the accelerator's investments.. The more the success of existing investments at a deal-flow accelerator, the higher the chance to attract future venture capital funds. This will eventually drive higher input seed funding for new ventures, thus completing the cycle.

Variations across ecosystems can be explained by the environment in which these accelerators operate. The external environment plays a major role in the RBV theory: weak environment drives tepid performance outputs of firms. Although the GSF accelerator in India provided substantial input funding (comparable to the US accelerators), the performance of its ventures in the areas of funding, survivability, and growth were inferior. This validates the explanation provided by Lyles et al. (2004) related to the transitional nature of emerging environment and the inability of firms to convert the resources acquired into superior performance. Even though the Indian ecosystem is rated well on the TEA innovation and almost comparable to the US ecosystem, the cost of starting a business in India is almost 24 times higher than in the USA. This is due to the difficult policy environment in the country. The new ventures in India spend more time dealing with regulatory hurdles 
rather than on improvising the innovation and taking it to the market. On similar grounds, from an investor perspective, the environment in India and Brazil are not conducive for investors to get a return on their investments for two reasons. Firstly, high failure rate is coupled with four times worse recovery rate for failed investments compared to the USA. Secondly, India and Brazil have much fewer exits through initial public offerings (IPO) compared to the US market. These hurdles keep investors at bay from doing multiple further rounds of investment to accelerated new ventures after having raised initial seed funding from their accelerators. Indeed, bureaucratic structures, difficult policy environments, and external markets hamper entrepreneurial performances of new ventures. This provides evidence to the impact of external ecosystem on the RBV theory and helps to examine tepid impacts of accelerators in Brazil and India.

\section{CONCLUSIONS}

This is the first of its kind study assessing and contrasting six accelerators and their influence on the performance of 1286 new venture firms, both within and across three countries: the USA, Brazil, and India. Based on three important dimensions of accelerators - i.e. human capital, network capabilities, and external environment - with twelve contributing factors, the impact of the accelerators' influence on new venture firms was analysed with four metrics: funding, survivability, growth, and acquisitions. Accelerators can effectively improve funding performance outcomes through channelling input seed funding in both developed and emerging ecosystems. Accelerator founder human capital is severely deficient in Brazil and India and requires augmentation. The external environment in emerging ecosystems and its transitional nature impact the resources facilitated by the accelerators and also dampens the performance of accelerators and the new ventures that graduate from them. In order to overcome local ecosystem shortcomings and improve their efficacies, accelerators in emerging ecosystems should ameliorate their resources and capabilities by adding resources from mature ecosystems. However, the onus is on the policy makers in emerging countries so as to eventually ease the regulatory frameworks to avoid resource leakages in their accelerators.

The study has several implications for managers/practitioners. From a practitioner's perspective, this study provides insights into influencing the key metrics that impact new venture performances to leadership teams of accelerators. Input resources of accelerators should be increased by partnering with mature ecosystems so as to improve the network capabilities such as input seed funding or the number of mentors and investors. Accelerators in emerging ecosystems have deficient human capital, so they must scout for managers from their local ecosystems who previously developed start-ups and have sound industry experience.

From a research implication perspective, the variables and the framework explored in this study could be used, because we identified building blocks for future studies of accelerators as detailed set of parameters by looking at relevant literature on strategic management, the RBV theory, and new venture performance.

Ecosystem factors - viz. Recovery rate, Ease of doing business, and Starting a Business - played a major role in determining total funding, survival, and growth outcomes, respectively. This work draws the attention of policy-makers to examine the resilience of their regulatory frameworks in order to avoid resource leakages in their accelerators. 
From a social implication perspective, successful structured accelerator programs create more entrepreneurs in society, as several uncertainties and risks are tackled by previous cohorts graduates. National economic growth is directly impacted by the growth of new ventures, in which external ecosystem plays an important role, as revealed by this study. The average total funding raised by YCOM ventures is 16 times that of Indian accelerated ventures. Policy-makers must be aware of the fact that an unfavourable ecosystem adversely impacts jobs and investments from global investors.

The limitation of this study is that although this work focused on building a model to assess the performance of deal-flow accelerators, the study was intentionally restricted to two successful accelerators per country. There is room to scale this work to a larger number of deal-flow accelerators and extend it to other categories of accelerators backed by corporates and governments. We would like to caution researchers to develop appropriate category-specific measures, as we did in this study. Moreover, our study should be extended to demarcate and analyse the roles of deal-flow accelerator stakeholders, specifically to explore the impact created by venture capital investors. Understanding the impact of weak ecosystems on founders and their response to mitigate ecosystem risks would be an interesting avenue for further research.

\section{REFERENCES}

Acs, Z., \& Armington, C. (2004). Employment growth and entrepreneurial activity in cities. Regional Studies, 38(8), 911-927. https://doi.org/10.1080/0034340042000280938

Amezcua, A.S., Grimes, M.G., Bradley, S.W., \& Wiklund, J. (2013). Organizational sponsorship and founding environments: a contingency view on the survival of business-incubated firms, 1994-2007. Academy of Management Journal, 56(6), 1628-1654. https://doi.org/10.5465/amj.2011.0652

Amit, R., \& Schoemaker, P.J. (1993). Strategic assets and organizational rent. Strategic Management Journal, 14(1), 33-46.

Battistella, C., De Toni, A.F., \& Pessot, E. (2017). Open accelerators for start-ups success: a case study. European Journal of Innovation Management, 20(1), 80-111. https://doi.org/10.1108/EJIM-102015-0113

Besley, T. (2015). Law, regulation, and the business climate: The nature and influence of the World Bank Doing Business project. Journal of Economic Perspectives, 29(3), 99-120. https://doi.org/10.1257/jep.29.3.99

Block, J., \& Sandner, P. (2009). What is the effect of the financial crisis on venture capital financing? Empirical evidence from US Internet start-ups. Venture Capital,11(4), 295-309. https://doi.org/10.1080/13691060903184803

Bloom, N., Genakos, C., Sadun, R., \& Van Reenen, J. (2012). Management practices across firms and countries. Academy of Management Perspectives, 26(1), 12-33. https://doi.org/10.5465/amp.2011.0077

Bøllingtoft, A. (2012). The bottom-up business incubator: Leverage to networking and cooperation practices in a self-generated, entrepreneurial-enabled environment. Technovation, 32(5), 304315. https://doi.org/10.1016/j.technovation.2011.11.005

Bosma, N. (2013). The Global Entrepreneurship Monitor (GEM) and its impact on entrepreneurship research. Foundations and Trends in Entrepreneurship, 9(2), 143-248. http://dx.doi.org/10.1561/0300000033 
Business, D. (2013). Doing business 2014: Understanding regulations for small and medium-size enterprises.Washington DC. Retrieved from https://www.doingbusiness.org/ on October 15, 2019.

Bryl, Ł., \& Truskolaski, S. (2017). Human capital reporting and its determinants by Polish and German publicly listed companies. Entrepreneurial Business and Economics Review, 5(2), 195. https://doi.org/10.15678/EBER.2017.050211

Cacciolatti, L., Rosli, A., Ruiz-Alba, J.L., \& Chang, J. (2020). Strategic alliances and firm performance in startups with a social mission. Journal of Business Research, 106, 106-117. https://doi.org/10.1016/j.jbusres.2019.08.047

Cohen, S., Fehder, D.C., Hochberg, Y.V., \& Murray, F. (2019). The design of startup accelerators. Research Policy, 48(7), 1781-1797. https://doi.org/10.1016/j.respol.2019.04.003

Cohen, S., \& Hochberg, Y.V. (2014). Accelerating startups: The seed accelerator phenomenon. http://dx.doi.org/10.2139/ssrn.2418000

Dahms, S., \& Kingkaew, S. (2016). University business incubators: An institutional demand side perspective on value adding features. Entrepreneurial Business and Economics Review, 4(3), 41-56. https://doi.org/10.15678/EBER.2016.040304

De Toni, A., \& Tonchia, S. (2003). Strategic planning and firms' competencies: Traditional approaches and new perspectives. International Journal of Operations \& Production Management, 23(9), 947-976. https://doi.org/10.1108/01443570310491729

Eveleens, C.P., van Rijnsoever, F.J., \& Niesten, E.M. (2017). How network-based incubation helps startup performance: a systematic review against the background of management theories. The Journal of Technology Transfer, 42(3), 676-713. https://doi.org/10.1007/s10961-016-9510-7

Eugene, L.Y., \& Yuan, S.T.D. (2012). Where's the money? the social behavior of investors in facebook's small world. In Proceedings of the 2012 International Conference on Advances in Social Networks Analysis and Mining (ASONAM 2012) (pp. 158-162). IEEE Computer Society. https://doi.org/10.1109/ASONAM.2012.36

Gonzalez-Uribe, J., \& Leatherbee, M. (2018). The effects of business accelerators on venture performance: Evidence from start-up chile.The Review of Financial Studies, 31(4), 1566-1603. https://doi.org/10.1093/rfs/hhx103

Goswami, K., Mitchell, J.R., \& Bhagavatula, S. (2018). Accelerator expertise: Understanding the intermediary role of accelerators in the development of the Bangalore entrepreneurial ecosystem. Strategic Entrepreneurship Journal, 12(1), 117-150. https://doi.org/10.1002/sej.1281

Grant, R.M. (1991). The resource-based theory of competitive advantage: implications for strategy formulation. California Management Review, 33(3), 114-135. https://doi.org/10.2307/41166664

Hallen, B.L., Bingham, C.B., \& Cohen, S. (2014). Do accelerators accelerate? A study of venture accelerators as a path to success?. In Academy of Management Proceedings (Vol. 2014, No. 1, p. 12955). Briarcliff Manor, NY 10510: Academy of Management. https://doi.org/10.5465/ambpp.2014.185

Hart, S.L. (1995). A natural-resource-based view of the firm. Academy of Management Review, 20(4), 986-1014. https://doi.org/10.5465/amr.1995.9512280033

Hochberg, Y.V. (2016). Accelerating entrepreneurs and ecosystems: The seed accelerator model. Innovation Policy and the Economy, 16(1), 25-51. https://doi.org/10.1086/684985

Hsu, D.H. (2007). Experienced entrepreneurial founders, organizational capital, and venture capital funding. Research Policy, 36(5), 722-741. https://doi.org/10.1016/j.respol.2007.02.022

Kanbach, D.K., \& Stubner, S. (2016). Corporate accelerators as recent form of startup engagement: The what, the why, and the how. Journal of Applied Business Research (JABR), 32(6), 1761-1776. https://doi.org/10.19030/jabr.v32i6.9822 
Kim, J.H., \& Wagman, L. (2014). Portfolio size and information disclosure: An analysis of startup accelerators. Journal of Corporate Finance, 29, 520-534. https://doi.org/10.1016/j.jcorpfin.2014.10.017

Ko, E.J., \& McKelvie, A. (2018). Signaling for more money: The roles of founders' human capital and investor prominence in resource acquisition across different stages of firm development. Journal of Business Venturing, 33(4), 438-454. https://doi.org/10.1016/j.jbusvent.2018.03.001

Klyver, K. (2008). An analytical framework for micro-level analysis of GEM data. International Journal of Entrepreneurship and Small Business, 6(4), 583-603. https://doi.org/10.1504/IJESB.2008.019503

Lisowska, R. (2016). The potential of business environment institutions and the support for the development of small and medium-sized enterprises. Entrepreneurial Business and Economics Review , 4(3), 85-101. https://doi.org/10.15678/EBER.2016.040307

Lyles, M.A., Saxton, T., \& Watson, K. (2004). Venture survival in a transitional economy. Journal of Management, 30(3), 351-375. https://doi.org/10.1016/j.jm.2003.03.001

Mansoori, Y., Karlsson, T., \& Lundqvist, M. (2019). The influence of the lean startup methodology on entrepreneur-coach relationships in the context of a startup accelerator. Technovation, 84, 3747. https://doi.org/10.1016/j.technovation.2019.03.001

Mayer-Haug, K., Read, S., Brinckmann, J., Dew, N., \& Grichnik, D. (2013). Entrepreneurial talent and venture performance: A meta-analytic investigation of SMEs. Research Policy, 42(6-7), 12511273. https://doi.org/10.1016/j.respol.2013.03.001

Meschi, P.X., \& Riccio, E.L. (2008). Country risk, national cultural differences between partners and survival of international joint ventures in Brazil. International Business Review, 17(3), 250-266. https://doi.org/10.1016/j.ibusrev.2007.11.001

Murphy, G.B., Trailer, J.W., \& Hill, R.C. (1996). Measuring performance in entrepreneurship research. Journal of Business Research, 36(1), 15-23. https://doi.org/10.1016/0148-2963(95)00159-X

Pauwels, C., Clarysse, B., Wright, M., \& Van Hove, J. (2016). Understanding a new generation incubation model: The accelerator. Technovation, 50, 13-24. https://doi.org/10.1016/j.technovation.2015.09.003

Penrose, E., \& Penrose, E.T. (2009).The Theory of the Growth of the Firm. Oxford University Press.

Porter, M.E. (1991). Towards a dynamic theory of strategy. Strategic Management Journal, 12(S2), 95-117. https://doi.org/10.1002/smj.4250121008

Radojevich-Kelley, N., \& Hoffman, D.L. (2012). Analysis of accelerator companies: An exploratory case study of their programs, processes, and early results. Small Business Institute Journal, 8(2), 54-70.

Smith, S.W., \& Hannigan, T.J. (2015). Swinging for the fences: How do top accelerators impact the trajectories of new ventures. Druid,15, 15-17.

Shetty, S., \& Sundaram, R. (2019). Funding acquisition drivers for new venture firms: Diminishing value of human capital signals in early rounds of funding. Problems and Perspectives in Management, 17(1), 78. http://dx.doi.org/10.21511/ppm.17(1).2019.08

Van Stel, A., Storey, D.J., \& Thurik, A.R. (2007). The effect of business regulations on nascent and young business entrepreneurship. Small Business Economics, 28(2-3), 171-186. https://doi.org/10.1007/s11187-006-9014-1

Uhm, C.H., Sung, C.S., \& Park, J.Y. (2018). Understanding the accelerator from resources-based perspective. Asia Pacific Journal of Innovation and Entrepreneurship, 12(3), 258-278. https://doi.org/10.1108/APJIE-01-2018-0001

Wise, S., \& Valliere, D. (2014). The impact on management experience on the performance of start-ups within accelerators. The Journal of Private Equity, 18(1), 9-19. https://doi.org/10.3905/jpe.2014.18.1.009 
Wong, P.K., Ho, Y.P., \& Autio, E. (2005). Entrepreneurship, innovation and economic growth: Evidence from GEM data. Small Business Economics, 24(3), 335-350. https://doi.org/10.1007/s11187-005-2000-1

Xu, S., Zhang, Q., Lü, L., \& Mariani, M.S. (2020). Recommending investors for new startups by integrating network diffusion and investors' domain preference. Information Sciences, 515, 103115. https://doi.org/10.1016/j.ins.2019.11.045

Yang, S., Kher, R., \& Lyons, T.S. (2018). Where Do Accelerators Fit in the Venture Creation Pipeline? Different Values Brought by Different Types of Accelerators. Entrepreneurship Research Journal, 8(4). https://doi.org/10.1515/erj-2017-0140

Yin, B., \& Luo, J. (2018). How do accelerators select startups? Shifting decision criteria across stages. IEEE Transactions on Engineering Management, 65(4), 574-589. https://doi.org/ 10.1109/TEM.2018.2791501

Żur, A. (2013). Entrepreneurial Orientation and Firm Performance: Challenges for Research and Practice. Entrepreneurial Business and Economics Review, 1(2), 7-28.

\section{Appendix}

Table 9. Literature review of accelerator studies

\begin{tabular}{|c|c|c|c|c|c|c|}
\hline $\begin{array}{l}\text { Au- } \\
\text { thor/Date }\end{array}$ & Research Focus & $\begin{array}{l}\text { Popula- } \\
\text { tion }\end{array}$ & $\begin{array}{c}\begin{array}{c}\text { Region } \\
\text { chosen } \\
\text { for study }\end{array} \\
\end{array}$ & $\begin{array}{c}\text { Theory } \\
\text { used }\end{array}$ & Findings & $\begin{array}{l}\text { Limitation/Fu- } \\
\text { ture scope }\end{array}$ \\
\hline $\begin{array}{l}\text { Radojevich } \\
\text { et al. } \\
(2012)\end{array}$ & $\begin{array}{l}\text { Exploratory case study } \\
\text { of accelerator (ACCL) } \\
\text { programs and pro- } \\
\text { cesses. }\end{array}$ & 5 ACCLs & the USA & RBV & $\begin{array}{l}\text { Mentorship } \\
\text { driven programs } \\
\text { provide entrepre- } \\
\text { neurs with access } \\
\text { to angel investors } \\
\text { and venture capi- } \\
\text { talists thereby in- } \\
\text { creasing start-up } \\
\text { success rates. } \\
\end{array}$ & $\begin{array}{l}\text { Only a few major } \\
\text { ACCLs existed in } \\
\text { this period of } \\
\text { study. Limited } \\
\text { data availability. }\end{array}$ \\
\hline $\begin{array}{l}\text { Hallen } \\
\text { et al. } \\
(2014)\end{array}$ & $\begin{array}{l}\text { The comparison of ac- } \\
\text { celerated and non-ac- } \\
\text { celerated ventures us- } \\
\text { ing speed to reach } \\
\text { milestones. Studied } \\
\text { portfolio ventures. }\end{array}$ & $\begin{array}{l}8 \text { ACCLs } \\
\text { and } 164 \\
\text { start-ups }\end{array}$ & $\begin{array}{l}\text { the USA } \\
\text { and Eu- } \\
\text { rope }\end{array}$ & None & $\begin{array}{l}\text { Some ACCLs ac- } \\
\text { celerate venture } \\
\text { gestation more } \\
\text { than others. }\end{array}$ & $\begin{array}{l}\text { Study based on a } \\
\text { developed econ- } \\
\text { omy. More quan- } \\
\text { titative analysis } \\
\text { recommended. }\end{array}$ \\
\hline $\begin{array}{l}\text { Cohen \& } \\
\text { Hochberg } \\
(2014)\end{array}$ & $\begin{array}{l}\text { The definition of seed } \\
\text { ACCLs difference from } \\
\text { incubators, angel in- } \\
\text { vestors, and benefits. }\end{array}$ & $\begin{array}{l}\text { multiple } \\
\text { ACCLs }\end{array}$ & the USA & - & \begin{tabular}{|l|} 
ACCLs distinct \\
from incubators. \\
New model of as- \\
sistance.
\end{tabular} & $\begin{array}{l}\text { Claims rigorous } \\
\text { research is much } \\
\text { needed when } \\
\text { data is available. }\end{array}$ \\
\hline $\begin{array}{l}\text { Kim \& } \\
\text { Wagman } \\
(2014)\end{array}$ & $\begin{array}{l}\text { The information gath- } \\
\text { ering role of } A C C L \text { in } \\
\text { certifying the value of } \\
\text { portfolio ventures to } \\
\text { outside investors. }\end{array}$ & $\begin{array}{l}\text { generic } \\
\text { study of } \\
\text { ACCL pro- } \\
\text { grams }\end{array}$ & None & None & $\begin{array}{l}\text { Potential ineffi- } \\
\text { ciency in certifica- } \\
\text { tion process of } \\
\text { ACCL. }\end{array}$ & $\begin{array}{l}\text { Based on a theo- } \\
\text { retical frame- } \\
\text { work. }\end{array}$ \\
\hline
\end{tabular}




\begin{tabular}{|c|c|c|c|c|c|c|}
\hline $\begin{array}{c}\text { Au- } \\
\text { thor/Date }\end{array}$ & Research Focus & $\begin{array}{l}\text { Popula- } \\
\text { tion }\end{array}$ & \begin{tabular}{|c|}
$\begin{array}{c}\text { Region } \\
\text { chosen } \\
\text { for study }\end{array}$ \\
\end{tabular} & $\begin{array}{c}\text { Theory } \\
\text { used }\end{array}$ & Findings & $\begin{array}{l}\text { Limitation/Fu- } \\
\text { ture scope }\end{array}$ \\
\hline $\begin{array}{l}\text { Wise \& } \\
\text { Valliere } \\
\text { (2014) }\end{array}$ & $\begin{array}{l}\text { Exit of start-ups from } \\
\text { North America acceler- } \\
\text { ators. }\end{array}$ & $\begin{array}{l}\text { Techstars } \\
\text { and DMZ } \\
\text { ACCL ven- } \\
\text { tures }\end{array}$ & $\begin{array}{l}\text { North } \\
\text { America }\end{array}$ & $\begin{array}{l}\text { Human } \\
\text { Capital }\end{array}$ & $\begin{array}{l}\text { Years of start-up } \\
\text { founder experi- } \\
\text { ence available in } \\
\text { the ACCL man- } \\
\text { agement team } \\
\text { has a beneficial } \\
\text { effect on the fail- } \\
\text { ure hazard of ten- } \\
\text { ant firms. }\end{array}$ & $\begin{array}{l}\text { Explanatory } \\
\text { model using only } \\
\text { two case studies. }\end{array}$ \\
\hline $\begin{array}{l}\text { Smith \& } \\
\text { Hannigan } \\
(2015)\end{array}$ & $\begin{array}{l}\text { Impact on the exit of } \\
\text { venture based on re- } \\
\text { ceived financing. Top } \\
\text { angel-group-funded } \\
\text { start-ups compared } \\
\text { with top ACCL-funded } \\
\text { start-ups. }\end{array}$ & $\begin{array}{l}619 \text { ven- } \\
\text { tures of } \\
\text { YCOM } \\
\text { and } \\
\text { Techstars. }\end{array}$ & the USA & None & $\begin{array}{l}\text { Participation in a } \\
\text { top ACCL pro- } \\
\text { gram increases } \\
\text { the speed of exit. }\end{array}$ & $\begin{array}{l}\text { Study limited to } \\
\text { two of the most } \\
\text { prominent ACCLs } \\
\text { in the USA. }\end{array}$ \\
\hline $\begin{array}{l}\text { Pauwels } \\
\text { et al. } \\
(2016)\end{array}$ & $\begin{array}{l}\text { Design lens as a theo- } \\
\text { retical framework for } \\
\text { analysing accelerator } \\
\text { elements and themes } \\
\text { to understand their } \\
\text { operating model. }\end{array}$ & $13 \mathrm{ACCLS}$ & $\begin{array}{l}\text { London, } \\
\text { Paris, } \\
\text { and Ber- } \\
\text { lin in Eu- } \\
\text { rope }\end{array}$ & $\begin{array}{l}\text { Design } \\
\text { lens }\end{array}$ & $\begin{array}{l}\text { The identification } \\
\text { of three different } \\
\text { types of ACCLs. } \\
\text { The importance } \\
\text { of a homogenous } \\
\text { study. }\end{array}$ & $\begin{array}{l}\text { Develop } \\
\text { measures for } \\
\text { each type. Study } \\
\text { portfolio ven- } \\
\text { tures to under- } \\
\text { stand ACCL im- } \\
\text { pact. }\end{array}$ \\
\hline $\begin{array}{l}\text { Kanbach \& } \\
\text { Stubner } \\
(2016)\end{array}$ & $\begin{array}{l}\text { ACCL case study using } \\
\text { the inductive research } \\
\text { method. }\end{array}$ & $\begin{array}{l}13 \text { corpo- } \\
\text { rate } A C- \\
C L s\end{array}$ & Germany & None & $\begin{array}{l}\text { Corporate ACCLs } \\
\text { insource innova- } \\
\text { tions and aid in } \\
\text { strategy and fi- } \\
\text { nance. } \\
\end{array}$ & $\begin{array}{l}\text { The effectiveness } \\
\text { of corporate AC- } \\
\text { CLs needs to be } \\
\text { studied. }\end{array}$ \\
\hline $\begin{array}{l}\text { Battistella } \\
\text { (2016) }\end{array}$ & $\begin{array}{l}\text { How the context of } \\
\text { open innovation of- } \\
\text { fered by } \\
\text { ACCLs can affect the } \\
\text { successful growth of } \\
\text { start-ups. }\end{array}$ & $\begin{array}{l}\text { ACCL } \\
\text { Searchca } \\
\text { mp }\end{array}$ & the UK & None & $\begin{array}{l}\text { Open environ- } \\
\text { ment can miti- } \\
\text { gate start-up fail- } \\
\text { ures. }\end{array}$ & $\begin{array}{l}\text { Single case } \\
\text { study. }\end{array}$ \\
\hline $\begin{array}{l}\text { Hochberg } \\
\text { (2016) }\end{array}$ & $\begin{array}{l}\text { Introduction to ACCL } \\
\text { model and its effect on } \\
\text { regional entrepreneur- } \\
\text { ial environment. }\end{array}$ & $\begin{array}{l}\text { concep- } \\
\text { tual study } \\
\text { of ACCLs }\end{array}$ & the USA & None & $\begin{array}{l}\text { A summary previ- } \\
\text { ous studies. ACCL } \\
\text { programs aid re- } \\
\text { gional economic } \\
\text { development } \\
\text { with social bene- } \\
\text { fit. }\end{array}$ & $\begin{array}{l}\text { ACCL research in } \\
\text { infancy. Role and } \\
\text { efficacy of ACCLs } \\
\text { must be studied. } \\
\text { Ecosystem pa- } \\
\text { rameters to be } \\
\text { explored. }\end{array}$ \\
\hline $\begin{array}{l}\text { Gonzalez } \\
\text { Uribe } \\
\text { et al. } \\
(2017)\end{array}$ & $\begin{array}{l}\text { The impact of Startup } \\
\text { Chile on venture per- } \\
\text { formance, education, } \\
\text { and funding, }\end{array}$ & $\begin{array}{l}\text { ACCL } \\
\text { Startup } \\
\text { Chile }\end{array}$ & Chile & None & $\begin{array}{l}\text { Funding matters } \\
\text { for new ventures. } \\
\text { More resources } \\
\text { should be pro- } \\
\text { vided. }\end{array}$ & Single ACCL. \\
\hline
\end{tabular}




\begin{tabular}{|c|c|c|c|c|c|c|}
\hline $\begin{array}{c}\text { Au- } \\
\text { thor/Date }\end{array}$ & Research Focus & $\begin{array}{l}\text { Popula- } \\
\text { tion }\end{array}$ & \begin{tabular}{|c|}
$\begin{array}{c}\text { Region } \\
\text { chosen } \\
\text { for study }\end{array}$ \\
\end{tabular} & $\begin{array}{c}\text { Theory } \\
\text { used }\end{array}$ & Findings & $\begin{array}{l}\text { Limitation/Fu- } \\
\text { ture scope }\end{array}$ \\
\hline $\begin{array}{l}\text { Chul Hyun } \\
\text { Uhm } \\
(2018)\end{array}$ & $\begin{array}{l}\text { Exploratory case study } \\
\text { of ACCL comparisons: } \\
\text { educational support, } \\
\text { financial investment, } \\
\text { network relation. }\end{array}$ & $\begin{array}{l}3 \text { ACCLS } \\
\text { each in } 2 \\
\text { countries }\end{array}$ & $\begin{array}{l}\text { South } \\
\text { Korea } \\
\text { and the } \\
\text { USA }\end{array}$ & RBV & $\begin{array}{l}\text { The number of } \\
\text { differences be- } \\
\text { tween ACCLs in } \\
\text { terms of the re- } \\
\text { sources. Entre- } \\
\text { preneurial talent } \\
\text { limited in South } \\
\text { Korea. }\end{array}$ & $\begin{array}{l}\text { Emprical analysis } \\
\text { to show statisiti- } \\
\text { cal significance } \\
\text { of ACCLs needed. } \\
\text { Rigorous case } \\
\text { study needed. }\end{array}$ \\
\hline $\begin{array}{l}\text { Yin \& Luo } \\
(2018)\end{array}$ & $\begin{array}{l}\text { Decision criteria of AC- } \\
\text { CLs while selecting } \\
\text { start-ups. Scoreboard } \\
\text { framework of } 30 \text { crite- } \\
\text { ria. }\end{array}$ & $\begin{array}{l}\text { Singapore } \\
\text { JFDI ACCL }\end{array}$ & $\begin{array}{l}\text { Singa- } \\
\text { pore }\end{array}$ & None & $\begin{array}{l}\text { Implicit decision } \\
\text { criteria identified. } \\
\text { Eight win criteria } \\
\text { for initial screen- } \\
\text { ing important. } \\
\text { Growth strategy } \\
\text { and prior start-up } \\
\text { experience criti- } \\
\text { cal. } \\
\end{array}$ & $\begin{array}{l}\text { Single ACCL. The } \\
\text { utility of the pre- } \\
\text { diction models } \\
\text { for different } \\
\text { stages are lim- } \\
\text { ited } \\
\text { by their low ac- } \\
\text { curacy (below } \\
80 \% \text { ). } \\
\end{array}$ \\
\hline $\begin{array}{l}\text { Yang } \\
\text { et al. } \\
(2018)\end{array}$ & $\begin{array}{l}\text { Fit of ACCLs in the ven- } \\
\text { ture pipeline system. } \\
\text { Placement in the three } \\
\text { subsystems to develop } \\
\text { entrepreneurs from } \\
\text { lower-level to higher- } \\
\text { level skills. }\end{array}$ & $\begin{array}{l}\text { study of } \\
\text { ACCL pro- } \\
\text { grams }\end{array}$ & None & None & $\begin{array}{l}\text { It is important to } \\
\text { conduct homoge- } \\
\text { nous studies. AC- } \\
\text { CLs are early- } \\
\text { stage finance pro- } \\
\text { viders. }\end{array}$ & $\begin{array}{l}\text { Study limited to } \\
\text { the clarification } \\
\text { of ACCL models } \\
\text { and their fit in } \\
\text { the venture capi- } \\
\text { tal pipeline. }\end{array}$ \\
\hline $\begin{array}{l}\text { Goswami } \\
\text { et al. } \\
(2018)\end{array}$ & $\begin{array}{l}\text { Effectiveness of six } \\
\text { Bangalore based AC- } \\
\text { CLs in improving the } \\
\text { ecosystem. }\end{array}$ & 6 ACCLS & $\begin{array}{l}\text { Banga- } \\
\text { lore, In- } \\
\text { dia }\end{array}$ & None & $\begin{array}{l}\text { ACCL play an in- } \\
\text { termediary role } \\
\text { by connecting } \\
\text { founders to the } \\
\text { regional ecosys- } \\
\text { tem. } \\
\end{array}$ & $\begin{array}{l}\text { The analysis of a } \\
\text { single geographic } \\
\text { region. }\end{array}$ \\
\hline $\begin{array}{l}\text { Cohen } \\
\text { et al. } \\
(2019)\end{array}$ & $\begin{array}{l}\text { Connections between } \\
\text { design and perfor- } \\
\text { mance. }\end{array}$ & $\begin{array}{l}\text { Explora- } \\
\text { tory } \\
\text { study of } \\
\text { ACCLs }\end{array}$ & the USA & $\begin{array}{l}\text { Human } \\
\text { Capital, } \\
\text { Design } \\
\text { lens }\end{array}$ & $\begin{array}{l}\text { The design of ac- } \\
\text { celerators is tied } \\
\text { to performance } \\
\text { outcomes. }\end{array}$ & $\begin{array}{l}\text { Explore impact } \\
\text { of accelerators } \\
\text { tied to business } \\
\text { models adopted } \\
\text { and objectives of } \\
\text { ACCLs. } \\
\end{array}$ \\
\hline $\begin{array}{l}\text { Mansoori } \\
\text { et al. } \\
(2019)\end{array}$ & $\begin{array}{l}\text { Entrepreneur coach } \\
\text { relationships in univer- } \\
\text { sity-based ACCL using } \\
\text { ethnographic study. }\end{array}$ & $\begin{array}{l}17 \text { ven- } \\
\text { tures }\end{array}$ & Sweden & & $\begin{array}{l}\text { Lean start-up } \\
\text { methodology in- } \\
\text { fluences the en- } \\
\text { trepreneur-coach } \\
\text { relationships. }\end{array}$ & $\begin{array}{l}\text { Challenges due } \\
\text { to legitimacy of } \\
\text { methodology } \\
\text { and nature of } \\
\text { the accelerated } \\
\text { ventures. }\end{array}$ \\
\hline
\end{tabular}

Source: own study. 


\section{Authors}

The contribution share of authors is equal and amounted to $1 / 3$ for each of them.

S. Shetty worked on the concept, R. Sundaram prepared statistical calculations, while K. Achuthan prepared the literature review.

\section{Snehal Shetty}

Assistant Professor, Amrita Vishwa Vidyapeetham. Manages the Accelerator program at Amrita $\mathrm{TBI}$, which has successfully graduated multiple cohorts. Research interests include entrepreneurship and new ventures.

Correspondence to: Snehal S., Amrita TBI, Kollam, Kerala, India. e-mail: snehal@amritatbi.com ORCID (1) http://orcid.org/0000-0002-5130-6283

\section{Ranjany Sundaram}

Ranjany Sundaram, Assistant Professor, Amrita Vishwa Vidyapeetham. Manages mentorship and funding for accelerator cohorts at Amrita TBI. Research interests include entrepreneurship and strategy management.

Correspondence to: Ranajny S., Amrita TBI, Kollam, Kerala, India. e-mail: ranjany@amritatbi.com ORCID (1) http://orcid.org/0000-0003-0884-944X

\section{Krishnashree Achuthan}

Krishnashree Achuthan, Professor, Amrita Vishwa Vidyapeetham, and CEO at the Amrita Technology Business Incubator (Amrita TBI) that has nurtured start-ups in India for over a decade. The Amrita TBI has also run accelerator programs. Research interests include strategy management and entrepreneurship.

Correspondence to: Krishnashree A., Amrita TBI, Kollam, Kerala, India. e-mail: krishsnashree@amritatbi.com

ORCID (1) http://orcid.org/0000-0003-2618-0882

\section{Acknowledgements and Financial Disclosure}

The authors would like to express their gratitude to Dr. Georg Gutjahr, Assistant Professor of Amrita Vishwa Vidyapeetham, for his guidance on statistical analysis and ML methods.

\section{Copyright and License}

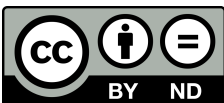

This article is published under the terms of the Creative Commons Attribution - NoDerivs (CC BY-ND 4.0) License http://creativecommons.org/licenses/by-nd/4.0/

Published by the Centre for Strategic and International Entrepreneurship - Krakow, Poland 
